\title{
Application of an Aqueous Extract of Cotton Seed as a Corrosion Inhibitor for Mild Steel in HCl Media
}

\author{
Isabel da Silva Hernandes ${ }^{a}$, Jéssica Nogueira da Cunha ${ }^{a}{ }^{\circledR}$, Carolina Araujo Santana $^{a}$, \\ José Guilherme Aquino Rodrigues ${ }^{a}$,Eliane D'Elia ${ }^{a^{*}} \mathbb{D}$ \\ ${ }^{a}$ Universidade Federal do Rio de Janeiro, Instituto de Quimica, Cidade Universitária, 21941-909, \\ Rio de Janeiro, RJ, Brazil.
}

Received: May 30, 2020; Revised: October 24, 2020; Accepted: November 11, 2020.

\begin{abstract}
The present work aims to study the aqueous cotton seeds extract as a natural inhibitor of the corrosion of mild steel in $1 \mathrm{~mol} \mathrm{~L}^{-1} \mathrm{HCl}$ using gravimetric tests, potentiodynamic polarization curves, electrochemical impedance measurements and surface morphological analysis by scanning electron microscopy (SEM). The aqueous cotton seed extract acted as a good corrosion inhibitor reaching an inhibition efficiency of $95.7 \%$ after $24 \mathrm{~h}$ of immersion for $800 \mathrm{mg} \mathrm{L}^{-1}$ inhibitor concentration. For the gravimetric tests varying the temperature, a decrease of the activation energy $(E a)$ was observed, suggesting a chemical adsorption on the surface of the metal. $400 \mathrm{mg} \mathrm{L}^{-1}$ of the high molecular weight fraction isolated from the total extract showed inhibition efficiency equal to $800 \mathrm{mg} \mathrm{L}^{-1}$ of the total extract, $97.3 \%$ and $94.2 \%$ from electrochemical impedance and polarization curves data, respectively, suggesting that the macromolecules present a fundamental participation in the inhibitive process.
\end{abstract}

Keywords: Mild steel, corrosion inhibitor, cotton seed, natural products.

\section{Introduction}

Corrosive processes are directly or indirectly linked to our daily lives. According to Leitão and Gentil ${ }^{1}$, corrosion means the physicochemical deterioration of a material in a given medium and depending on the wear of the material, various forms of corrosion are considered.

Corrosion is a problem present in many places, such as industries, buildings, viaducts, as well as ancient and modern works of $\mathrm{art}^{2}$. In this scenario, new studies are developing more sustainable methods, such as inhibitors, to control the effects of corrosion causing less damage to the environment.

The application of corrosion inhibitors is one of the most used and effective methods found in the literature ${ }^{3}$. However, some synthetic compounds can result in environmental damage, increasing the risk to human health. New biodegradable, inexpensive, and environmentally friendly products have been used for corrosion control ${ }^{4-13}$.

Adding small amounts of these natural extracts in solution may decrease the corrosion rate of the metal ${ }^{14-18}$. Natural inhibitors, for the most part, are considered adsorption inhibitors because they create a barrier between metal and electrolyte by blocking active sites and reducing metal dissolution and/or reduction reaction ${ }^{19}$.

Plant extracts contain many organic compounds, having heteroatoms such as $\mathrm{O}, \mathrm{P}, \mathrm{S}$ and $\mathrm{N}$ and $\pi$ electrons. These compounds can adsorb on the metal surface by the hetero atoms or $\pi$ electrons forming protective films ${ }^{20-22}$. In most cases, where natural extracts were applied as corrosion inhibitors, the inhibition efficiency obtained was associated

*e-mail: eliane@iq.ufrj.br with the presence of these organic molecules, including proteins and phenolic compounds ${ }^{4,18-19}$.

In this sense, oil-bearing seeds could be an excellent source of compounds with anti-corrosion properties. Brazil has a diversity of oilseeds such as cotton, castor beans, soybean and oil palm, a variety of plants and natural products ${ }^{23,24}$. Cotton seeds (Gossypium hirsitum L.) contain carbohydrates $(45.06 \% \mathrm{w} / \mathrm{w})$, lipids $(21.29 \% \mathrm{w} / \mathrm{w})$, proteins $(23.28 \% \mathrm{w} / \mathrm{w})$, water $(6.92 \% \mathrm{w} / \mathrm{w})$ and mineral residue known as ashes $(3.44 \% \mathrm{w} / \mathrm{w})^{25}$.

There is no work in the literature employing the aqueous extract of cotton seed as a natural corrosion inhibitor. As cotton seed presents high protein content, it may perform an important role in inhibiting steel acidic corrosion. In our previous works it was showed that the macromolecules as proteins and/or polyssacharides can be important in the inhibitive action towards the mild steel corrosion in acidic medium ${ }^{11,16,21-24,26}$. We have studied the inhibitory action of some aqueous oilseed extracts like castor beans and soybean meal extracts towards the mild steel corrosion in acidic media. $800 \mathrm{mg} \mathrm{L}^{-1}$ aqueous castor beans and soybean meal extracts showed inhibition efficiency of 94.4 and $88.8 \%$, respectively, from weight loss data after $2 \mathrm{~h}$ immersion ${ }^{23,24}$. The idea would be the use of the cotton cake, a residue obtained from the oil and biodiesel cotton production, as a new corrosion inhibitor.

Based on that fact, the objective of this work is to investigate the inhibitory action of the aqueous cotton seeds extract (ACSE) and its high molecular weight fractions (HMWF) in the mild steel corrosion in $1 \mathrm{~mol} \mathrm{~L}^{-1} \mathrm{HCl}$ by gravimetric tests, potentiodynamic polarization curves, electrochemical 
impedance measurements and surface analysis by scanning electron microscopy (SEM).

\section{Experimental}

\subsection{Materials and corrosive medium}

The chemical composition of the mild steel was (\% w): C: 0.18, P: 0.05, S: 0.05, Mn: 0.30 and the remaining percentage of Fe.

For gravimetric tests specimens of approximately $14 \mathrm{~cm}^{2}$ were submitted bythe following treatment: the mild steel coupons were previously abraded with 100 mesh water grit paper, sand blasted, washed with doubly distilled water, degreased with acetone and dried with hot air.

For electrochemical tests, the mild steel coupons were manually abraded with 100, 320, 600, 1000, 1200, 1500 and 2000 mesh water grit papers, washed with double distilled water, degreased with ethyl alcohol and dried with hot air.

All tests were performed using $1 \mathrm{~mol} \mathrm{~L}^{-1}$ hydrochloric acid solution as electrolyte which was prepared using $37 \%$ hydrochloric acid from Merck Co. (Darmstadt, Germany) and double distilled water.

\subsection{Obtaining the extract}

\subsubsection{Aqueous Cotton Seeds Extract (ACSE)}

The cotton seeds were supplied by Embrapa Algodão (Campina Grande, Paraíba, Brazil), ground and passed in the sieve. $30.0 \mathrm{~g}$ of cotton seeds were placed in $300 \mathrm{~mL}$ of double distilled boiling water for 1 hour infusion. Simple filtration was performed with cotton pad where the filtrate was placed in a freezer at $-4{ }^{\circ} \mathrm{C}$. Finally, the frozen filtrate was lyophilized (Liotop; model L101) at an average temperature of $-52{ }^{\circ} \mathrm{C}$, generating a dry powder as final product.

\subsubsection{High molecular weight fraction (HMWF)}

The high molecular weight fraction (HMWF) was isolated from the aqueous cotton seeds extract by diafiltration. Aqueous cotton seeds extract (ACSE) was poured in an ultrafiltration $3 \mathrm{kDa}$ cut-off membrane (Millipore) and submitted to centrifugation at $3500 \mathrm{rpm}$ for 60 minutes. The filtrate retained was frozen and lyophilized (HMWF). The liquid that passed through the $3 \mathrm{kDa}$ membrane, which corresponds to the low molecular weight fraction (LMWF) was also collected, frozen and lyophilized.

\subsection{Gravimetric tests}

The gravimetric measurements have been detailed in our previous works ${ }^{7-16}$. Initially, the weight loss measurements were performed with different immersion times (2, 4 and $24 \mathrm{~h}$ ) and varying the concentrations of the extract in 100, 200, 400 and $800 \mathrm{mg} \mathrm{L}^{-1}$. The temperature variation tests were performed at $25,35,45,55^{\circ} \mathrm{C}$ for $2 \mathrm{~h}$ of immersion in the absence and presence of $400 \mathrm{mg} \mathrm{L}^{-1}$ of the aqueous cotton seeds extract. The weight loss measurements were obtained according to ASTM G31-727. using analytical balance with precision of $0.1 \mathrm{mg}$. The inhibition efficiency (IE\%) was obtained using Equation $1^{10}$.
$\operatorname{IE}(\%)=\frac{W_{\text {corr }, 0}-W_{\text {corr }}}{W_{\text {corr }, 0}} \times 100$

Where, $W_{\text {corr }, 0}$ is the corrosion rate $\left(\mathrm{g} \mathrm{cm}^{-2} \mathrm{~h}^{-1}\right)$ in the absence of the inhibitor and $W_{\text {corr }}$ is the corrosion rate in the presence of the inhibitor.

The apparent activation energy of the system $(E a)$, kinetic parameter that relates to $W_{\text {corr }}$, was obtained using Equation $2^{10}$.

$\log W_{\text {corr }}=\frac{-E_{a}}{2.303 R T}+\log A$

Where, $W_{\text {corr }}$ is the corrosion rate $\left(\mathrm{g} \mathrm{cm}^{-2} \mathrm{~h}^{-1}\right), E_{a}$ is the apparent activation energy $\left(\mathrm{kJ} \mathrm{mol}^{-1}\right), \mathrm{A}$ is the pre-exponential factor, $T$ is the absolute temperature $(\mathrm{K})$ and $\mathrm{R}$ is the constant of ideal gases $\left(8.314 \mathrm{~J} \mathrm{~K}^{-1} \mathrm{~mol}^{-1}\right)$.

The activation enthalpy and entropy were calculated through an alternative Arrhenius equation (Equation 3$)^{28}$ :

$W_{\text {corr }}=\frac{R T}{N h} \exp \left(\frac{\Delta S^{*}}{R}\right) \exp \left(\frac{-\Delta H^{*}}{R T}\right)$

Where, $h$ is the Planck constant $\left(6.63 \times 10^{-34} \mathrm{~J} \mathrm{~s}\right), N$ is the Avogadro number $\left(6.02 \times 10^{23}\right), \Delta \mathrm{S}^{*}$ and $\Delta \mathrm{H}^{*}$ are the activation entropy and enthalpy, respectively.

\subsection{Electrochemical methods}

The electrochemical cell was composed of three electrodes: the reference electrode (saturated calomel electrode), the counter electrode (platinum wire with large area) and the working electrode (mild steel coupon with an area exposed to the corrosive medium equal to $0.785 \mathrm{~cm}^{2}$ ).

All the electrochemical tests were performed at concentrations of $10,50,100,200,400,800 \mathrm{mg} \mathrm{L}^{-1}$ for the aqueous cotton seeds extract and at $400 \mathrm{mg} \mathrm{L}^{-1}$ for $\mathrm{HMWF}$ obtained from ACSE.

The electrochemical experiments were performed using an Autolab PGSTAT 128 N potentiostat/galvanostat, controlled by GPES 4.9 electrochemical software from Metrohm Autolab (The Netherlands).

In order to perform electrochemical impedance measurements, the open circuit potential $(O C P)$ was first recorded as a function of time for 4000 seconds. The impedance was performed with polarized working electrode at the $O C P$, in a frequency range from $10 \mathrm{kHz}$ to $10 \mathrm{mHz}$, with 10 points per decade and amplitude of $10 \mathrm{mV}$. The inhibition efficiency (IE\%) obtained by electrochemical impedance was calculated according to Equation $4^{10}$.

$\operatorname{IE}(\%)=\frac{R_{p}-R_{p, 0}}{R_{p}} \times 100$

Where, $R_{p}$ e $R_{p, 0}$ are the polarization resistances obtained in the presence and absence of the inhibitor, respectively.

Potentiodynamic anodic and cathodic polarization curves were performed using a scan rate of $1 \mathrm{mV} \mathrm{s}^{-1}$ from $-300 \mathrm{mV}$ to $+300 \mathrm{mV}$ relative to the stable open-circuit corrosion potential. Corrosion current density $\left(j_{\text {corr }}\right)$, corrosion potential $\left(E_{\text {corr }}\right)$, anodic $(\beta \mathrm{a})$ and cathodic $(\beta \mathrm{c})$ Tafel constants were obtained by the Tafel extrapolation method.

The inhibition efficiency $(I E \%)$ was calculated from potentiodynamic polarization curves, according to Equation $5^{10}$. 


$$
\operatorname{IE}(\%)=\frac{j_{\text {corr }, 0}-j_{\text {corr }}}{j_{\text {corr }, 0}} \times 100
$$

Where, $j_{\text {corr }, 0}$ and $j_{\text {corr }}$ are the corrosion current densities $\left(\mathrm{mA} \mathrm{cm}^{-2}\right)$ in the absence and presence of the inhibitor, respectively.

\subsection{Surface analysis by Scanning Electron Microscopy (SEM)}

Mild steel coupons used for the surface analysis were mechanically abraded with 100, 320, 600, 1000, 1200, 1500 and 2000 mesh water grit papers and immersed in $1 \mathrm{~mol} \mathrm{~L}^{-1} \mathrm{HCl}$ in the absence and presence of $400 \mathrm{mg} \mathrm{L}^{-1}$ of the inhibitor (extratcs and HMWF) at room temperature for $2 \mathrm{~h}$.

The analysis was performed in a scanning electron microscope (FEI QUANTA 200) with an acceleration voltage of $20 \mathrm{kV}$. The images were obtained with 2000 times of magnification.

Table 1. Weight loss assays for mild steel in $1 \mathrm{~mol} \mathrm{~L}^{-1} \mathrm{HCl}$ varying ACSE concentration and immersion time.

\begin{tabular}{|c|c|c|c|c|}
\hline \multirow{2}{*}{$\begin{array}{c}\text { Immersion } \\
\text { time (h) }\end{array}$} & \multirow{2}{*}{$\frac{[\mathrm{ACSE}]}{\left(\mathrm{mg} \mathrm{L}^{-1}\right)}$} & \multirow{2}{*}{$\begin{array}{c}W_{\text {corr }} \\
\left(\mathrm{g} \mathrm{cm}^{-2} \mathrm{~h}^{-1}\right)\end{array}$} & \multirow{2}{*}{$I E(\%)$} & \multirow{2}{*}{$S D_{I E}(\%)$} \\
\hline & & & & \\
\hline \multirow[t]{4}{*}{2} & 0 & $2.8 \times 10^{-3}$ & - & - \\
\hline & 200 & $6.7 \times 10^{-4}$ & 76.1 & 0.5 \\
\hline & 400 & $5.4 \times 10^{-4}$ & 80.7 & 0.5 \\
\hline & 800 & $5.0 \times 10^{-4}$ & 82.1 & 1.5 \\
\hline \multirow[t]{4}{*}{24} & 0 & $1.5 \times 10^{-3}$ & - & - \\
\hline & 200 & $9.0 \times 10^{-5}$ & 94.0 & 1.3 \\
\hline & 400 & $8.7 \times 10^{-5}$ & 94.2 & 1.4 \\
\hline & 800 & $6.4 \times 10^{-5}$ & 95.7 & 1.7 \\
\hline
\end{tabular}

$S D_{I E}:$ standard deviation.

Table 2. Temperature effect on the corrosion of mild steel in $1 \mathrm{~mol}$ $\mathrm{L}^{-1} \mathrm{HCl}$ in the absence and presence of ACSE.

\begin{tabular}{|c|c|c|c|c|}
\hline \multirow{3}{*}{$\begin{array}{c}\text { Temperature } \\
\left({ }^{\circ} \mathrm{C}\right)\end{array}$} & \multirow{2}{*}{ Blank } & With & \multirow{3}{*}{$\begin{array}{c}I E \\
(\%)\end{array}$} & \multirow{3}{*}{$\begin{array}{l}S D_{I E} \\
(\%)\end{array}$} \\
\hline & & Inhibitor & & \\
\hline & $W_{\text {corr }}\left(\mathrm{g} \mathrm{cm}^{-2} \mathrm{~h}^{-1}\right)$ & $W_{\text {corr }}\left(\mathrm{g} \mathrm{cm}^{-2} \mathrm{~h}^{-1}\right)$ & & \\
\hline 25 & $2.8 \times 10^{-3}$ & $5.0 \times 10^{-4}$ & 82.1 & 0.7 \\
\hline 35 & $4.5 \times 10^{-3}$ & $7.0 \times 10^{-4}$ & 84.4 & 1.6 \\
\hline 45 & $7.0 \times 10^{-3}$ & $1.0 \times 10^{-3}$ & 85.7 & 1.0 \\
\hline 55 & $1.2 \times 10^{-2}$ & $1.3 \times 10^{-3}$ & 89.2 & 0.4 \\
\hline
\end{tabular}

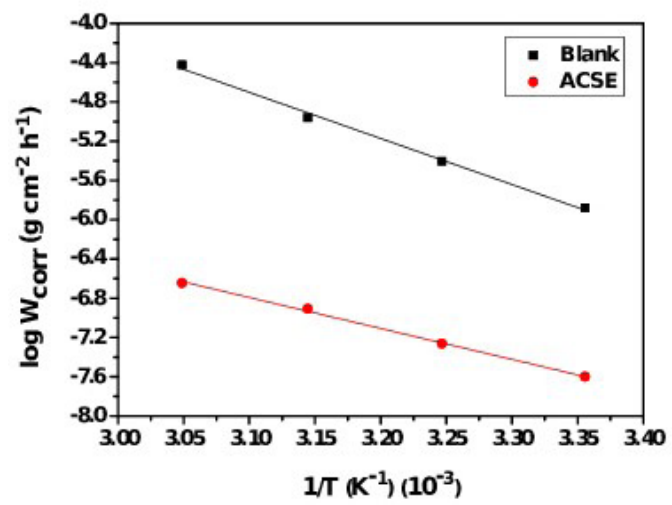

\section{Results and Discussion}

\subsection{Gravimetric Tests}

Table 1 presents the average corrosion rates $\left(W_{c o r r}\right)$, their standard deviations (SD) and the corrosion efficiencies (IE) for different immersion times in the absence and presence of ACSE.

The results presented in Table 1 indicated that the addition of the aqueous cotton seed extract reduced the corrosion rates of the mild steel in acid medium and this reduction increased with the extract concentration and the immersion time. For the ACSE concentration of $200 \mathrm{mg} \mathrm{L}^{-1}$, for example, $I E$ ranged from $76 \%$ at 2 hours of immersion to $94 \%$ at 24 hours. Therefore, the addition of ACSE, even at low concentrations, indicates the adsorption of the extract components on the mild steel, occupying the active sites, creating a protective layer on the metallic surface ${ }^{29,30}$.

Table 2 shows the effect of temperature on the inhibitory efficiency of the aqueous cotton seed extract.

The data of Table 2 presented an increase in corrosion rates with temperature, which occurs for blank assays and those containing ACSE. Nevertheless, IE values increases with temperature, indicating an adsorption process of chemical nature, where organic molecules from the extract adsorb on the steel surface involving charge sharing or transfer from the inhibitor molecules present in the ACSE to the mild steel surface, having $I E$ percentages varying from $82 \%$ to $89 \%$ in the temperature range of $25{ }^{\circ} \mathrm{C}$ to $55^{\circ} \mathrm{C}$, respectively. The increase in $I E$ suggests that the temperature increase provides the water desorption from the metallic surface, leading to more active sites for inhibitory molecules to adsorb on the metallic surface ${ }^{31,32}$.

From the results of Table 2, the Arrhenius plot was obtained (Figure 1A) and the apparent activation energy $\left(E_{a}\right)$ of the corrosive process was acquired based on the Arrhenius equation (Equation 2). Plotting $\log W_{\text {corr }}\left(\mathrm{g} \mathrm{cm}^{-2} \mathrm{~h}^{-1}\right) v s .1 / T\left(\mathrm{~K}^{-1}\right)$ the $E_{a}$ value was calculated for both uninhibited and inhibited systems.

An alternative form of the Arrhenius equation (Equation 3) was used to calculate the activation entropy and enthalpy related to the mild steel corrosion process in the absence and presence of the extract. Similarly, the plot of $\ln \left(W_{\text {corr }} / T\right)\left(\mathrm{g} \mathrm{cm}^{-2} \mathrm{~h}^{-1} \mathrm{~K}^{-1}\right)$ vs. $1 / T\left(\mathrm{~K}^{-1}\right)$ provides a line which

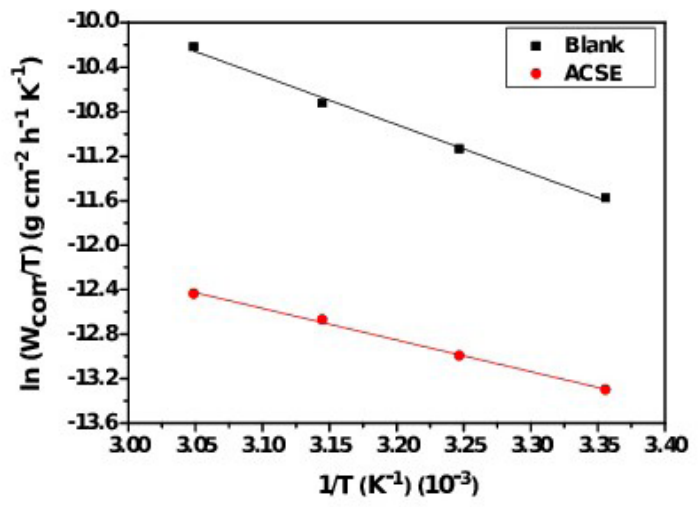

Figure 1. Arrhenius plots of: (A) $\left(\log W_{c o r r} v s .1 / T\right) ;(\mathrm{B})\left(\log \left(W_{\text {corr }} / T\right) v s .1 / T\right)$ for the mild steel corrosion in the absence and presence of ACSE. 


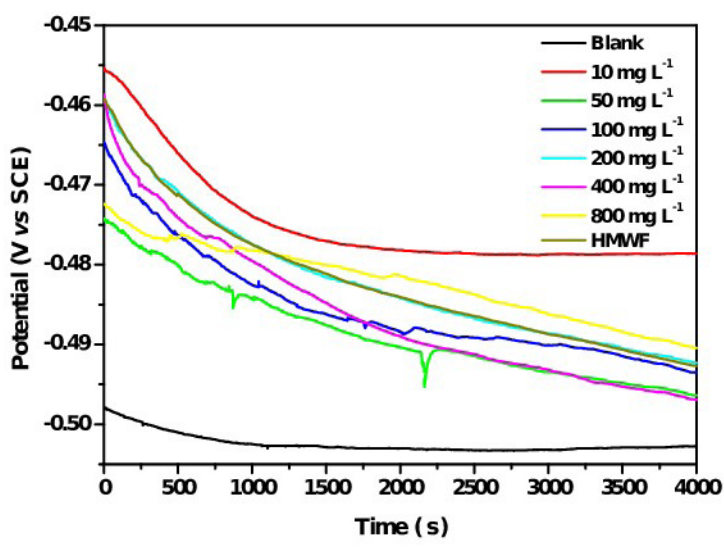

Figure 2.OCP plots of mild steel in $1 \mathrm{~mol} \mathrm{~L}^{-1} \mathrm{HCl}$ at different concentrations of ACSE and at $400 \mathrm{mg} \mathrm{L}^{-1}$ of HMWF.

Table 3. Thermodynamic activation functions of the corrosion processin the absence and presence of ACSE.

\begin{tabular}{cccc}
\hline & $\boldsymbol{E}_{\boldsymbol{a}}\left(\mathrm{kJ} \mathrm{mol}^{-1}\right)$ & $\boldsymbol{\Delta} \mathbf{H}^{*}\left(\mathrm{~kJ} \mathrm{~mol}^{-1}\right)$ & $\boldsymbol{\Delta} \mathbf{S} *\left(\mathbf{J ~ m o l}^{-\mathbf{1}} \mathbf{K}^{-\mathbf{1}}\right)$ \\
\hline Blank & 39.0 & 36.4 & -172 \\
\hline ACSE & 26.2 & 23.6 & -166 \\
\hline
\end{tabular}

slope is $-\Delta H^{*} / \mathrm{R}$ and linear coefficient of $\ln (\mathrm{R} / N h)+\Delta \mathrm{S} * / \mathrm{R}$. Those parameters allow us to obtain $\Delta \mathrm{H}^{*}$ and $\Delta \mathrm{S}^{*}$ values (Figure 2B). All the thermodynamic activation functions of the corrosion process are presented in Table 3.

In the presence of the extract, the $E_{a}$ and $\Delta \mathrm{H}^{*}$ values were $26.2 \mathrm{~kJ} \mathrm{~mol}^{-1}$ and $23.6 \mathrm{~kJ} \mathrm{~mol}^{-1}$, respectively, where as for the blank assay these parameters were $39.0 \mathrm{~kJ} \mathrm{~mol}^{-1}$ and $36.4 \mathrm{~kJ} \mathrm{~mol}^{-1}$, corroborating with the assumption of a chemisorption process where molecules from the extract share or donate electrons to the metal surface. Both activation enthalpies were positive, indicating that the mild steel dissolution process was endothermic. Besides that, it is noticed for both uninhibited and inhibited systems that $E_{a}$ values are greater than $\Delta \mathrm{H}^{*}$ which suggests that the corrosion process involves a gaseous reaction; in this case, the reduction of hydrogen ions to hydrogen gas in the cathodic process. The difference $E_{a}-\Delta \mathrm{H}^{*}$ is equal to RT $\left(2.6 \mathrm{~kJ} \mathrm{~mol}^{-1}\right)$, suggesting that the metal dissolution is a unimolecular reaction ${ }^{33}$. Activation entropies were negative both in the absence $\left(\Delta \mathrm{S}^{*}=-172 \mathrm{~J} \mathrm{~mol}^{-1} \mathrm{~K}^{-1}\right)$ and presence of the inhibitor $\left(\Delta \mathrm{S}^{*}=-166 \mathrm{~J} \mathrm{~mol}^{-1} \mathrm{~K}^{-1}\right)$, indicating that the activated complex in the determinant step is related more to an association process than a dissociation one $\mathrm{e}^{31-35}$.

\subsection{Electrochemical assays}

The high molecular fraction (HMWF) was also investigated by electrochemical measurements. This study was performed to elucidate the compounds class responsible for the inhibitory action of the ACSE towards the mild steel corrosion in $1 \mathrm{~mol} \mathrm{~L}^{-1} \mathrm{HCl}$.

\subsubsection{Open circuit potential (OCP)}

Open circuit potentials $(O C P)$ were recorded for mild steel in the presence and absence of inhibitor during $4000 \mathrm{~s}$. Figure 2 shows that the potential decreases quickly in the first minutes of immersion due to the dissolution process of the air formed oxide film and the attack on the mild steel surface ${ }^{36}$.

The steady open circuit potential is acquired quite soon for the blank assay where as with the addition of inhibitor a longer period is required to stabilize, around $2000 \mathrm{~s}$ for $10 \mathrm{mg} \mathrm{L}^{-1}$ of ACSE, and around $4000 \mathrm{~s}$ for higher ACSE concentration, with increase of $O C P$ for positive values. The stabilized $O C P$ for the blank was $-503 \mathrm{mV}$ while in the presence of the inhibitors dislocates the $O C P$ towards positive values which stabilized at -490 and $-493 \mathrm{mV}$ for $800 \mathrm{mg} \mathrm{L}^{-1}$ of ACSE and $400 \mathrm{mg} \mathrm{L}^{-1}$ of HMWF, respectively. The HMWF presented the same $O C P$ behavior seen with the ACSE. All curves show a slight anodic shift with respect to the blank with a maximum displacement of $24 \mathrm{mV}$ for $O C P$, demonstrating that the extracts act as a mixed-type inhibitor at open potential circuit with a bit anodic character.

\subsubsection{Electrochemical Impedance Spectroscopy (EIS)}

Figure 3 shows the Nyquist diagrams for mild steel in $1 \mathrm{~mol} \mathrm{~L}^{-1} \mathrm{HCl}$ solution in the absence (Figure 3A) and presence of ACSE at different concentrations as well as at $400 \mathrm{mg} \mathrm{L}^{-1}$ of its HMWF (Figure 3B).

In the absence of the ACSE, only one capacitive loop was observed in all frequency range which could be attributed to the charge transfer and double layer capacitance. This loop is depressed and is often attributed to dispersion effects, which have been ascribed to surface roughness and in homogeneities during corrosion ${ }^{8,10}$. The addition of ACSE as well as its HMWF did not change the result, indicating that the corrosion mechanism remained the same for all the studied cases.

Nyquist plots were analyzed based on an equivalent circuit shown in Figure 4, where $R_{s}$ is the solution resistance, $R_{p}$ is the polarization resistance and $C P E$ is the constant phase element. The constant phase element $(C P E)$ was introduced into the circuit in place of the pure capacitor of the double electric layer.

The impedance of the $C P E$ is expressed by the following Equation $6^{11,37}$ :

$$
Z_{C P E}=\frac{1}{Y_{o}(j \omega)^{n}}
$$

Where, $Y_{0}$ is the magnitude of $C P E$ and $n$ represents the deviation from the ideal behavior falling between -1 and 1 , $\omega_{\max }=2 \pi f_{\max }$ and $\mathrm{j}^{2}=-1$.

The double layer capacitance $(C d l)$ was then acquired through the CPE magnitude, according to the Equation $7^{11}$ :

$$
C_{d l}=Y_{0}\left(\omega_{\max }\right)^{n-1} C_{d l}=Y_{0}\left(2 \pi f_{\max }\right)^{n-1}
$$

Where, $Y_{0}$ is the magnitude of $C P E, \mathrm{n}$ is the deviation from ideal behavior, $\omega_{\max }=2 \pi f_{\max }$, and $f_{\max }$ the frequency where the imaginary component of the impedance is maximal.

Table 4 displays the parameters achieved from the electrochemical impedance analyses at different ACSE concentrations and at $400 \mathrm{mg} \mathrm{L}^{-1}$ of HMWF.

The data exposed on Table 4 and the electrochemical impedance diagrams presented in Figure $3 \mathrm{~B}$ point out that extracts addition in the corrosive solution leads to a decrease in the double layer capacitance and an increase 

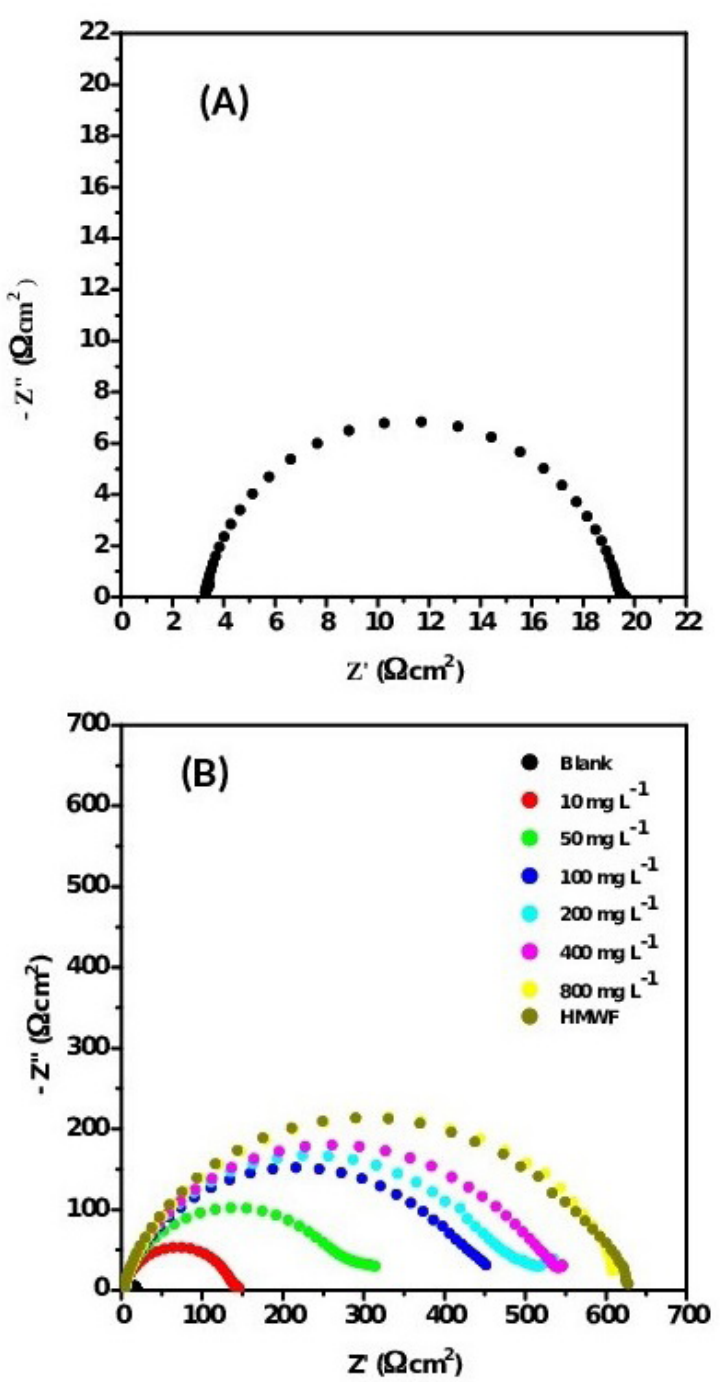

Figure 3. Nyquist plots obtained for mild steel in $1 \mathrm{~mol} \mathrm{~L}^{-1} \mathrm{HCl}(\mathrm{A})$ in the absence of inhibitor and (B) in the presence of different concentrations ACSE and at $400 \mathrm{mg} \mathrm{L}^{-1}$ of its HMWF.

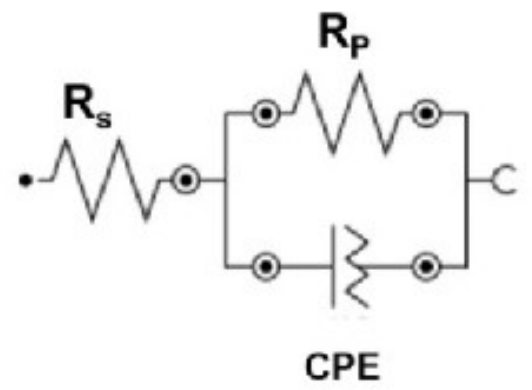

Figure 4. Equivalent circuit used for impedance data simulations.

in the polarization resistance, demonstrating that the adsorption process from the molecules of the extracts is occurring which corroborates the gravimetric results ${ }^{32}$. The extract concentration increase provides an increase in the capacitive loop diameter and, consequently, higher values of $R_{p}$ are obtained, which increases the inhibition efficiency, reaching a maximum value of $97.3 \%$ at $800 \mathrm{mg} \mathrm{L}^{-1}$ of ACSE. It is also stated that extremely low concentrations of ACSE provided a high $I E$ result as $88.5 \%$ for $10 \mathrm{mg} \mathrm{L}^{-1}$, and that the presence of $400 \mathrm{mg} \mathrm{L}^{-1}$ of the HMWF showed a similar loop seen for $800 \mathrm{mg} \mathrm{L}^{-1}$ of ACSE; resulting in the same $I E(97.3 \%)$. These results suggest once again that the macromolecules can be the main responsible for the inhibitory effect $\mathrm{t}^{10,11,16,23,24,26}$.

The diagrams of Bode (Figure 5) show a single time constant for all curves with a little frequency shift towards lower frequencies in the presence of the inhibitor, where the maximum phase angle for the blank assay is close to $39^{\circ}$ and this value increases significantly in the presence of $10 \mathrm{mg} \mathrm{L}^{-1}$ of $\operatorname{CSE}\left(\sim 61^{\circ}\right)$, however above $50 \mathrm{mg} \mathrm{L}^{-1}$ the phase angle keeps quite constant, achieving a value close to $65^{\circ}$ at $800 \mathrm{mg} \mathrm{L}^{-1}$. Higher phase angles were obtained for the samples containing the ACSE and its HMWF, suggesting that a protective film was formed in these conditions.

\subsubsection{Adsorption isotherms}

The interaction between the inhibitor and the metal surface can be described by adsorption isotherms. These isotherms require the degree of surface coverage $(\theta)$ for different inhibitor concentrations, which were calculated using the values $I E$ shown in Table 4, according to the Equation $8^{10}$.

$\theta=\frac{I E}{100}$

In order to evaluate the adsorption process of the inhibitory molecules contained in ACSE on the mild steel surface, the adsorption isotherms of Langmuir, Temkin, Flory-Huggins and El-Awady were evaluated and the data obtained are presented in Table 5 and Figure 6. Figure 6 and Table 5 show that the Langmuir isotherm showed a better linear correlation, with a linear correlation coefficient of 0.9999 and an angular coefficient of 1.0264 , suggesting the formation of a protective monolayer on the metal surface with a fixed number of adsorption sites and each site holds an adsorbate with no interaction between the adsorbate molecules ${ }^{9}$. Although the excellent linear correlation shown in Table 5, the obtained angular coefficient deviated from one unit, allowing to suggest the interaction between adsorbed molecules of the inhibitor or the relation between active site for each adsorbed molecule is not of one unit ${ }^{9-22}$.

\subsubsection{Potentiodynamic polarization curves}

Figure 7 shows the polarization curves for mild steel in 1 mol L ${ }^{-1} \mathrm{HCl}$ solution, in the absence and presence of ACSE with concentrations of 10, 50, 100, 200, 400, $800 \mathrm{mg} \mathrm{L}^{-1}$ and at $400 \mathrm{mg} \mathrm{L}^{-1}$ of its HMWF. Table 5 presents the kinetic parameters acquired from the Tafel extrapolation method.

Figure 7 and Table 6 point out the decrease of the anodic and cathodic current densities with the presence of the ACSE and its HMWF if compared to the system without the inhibitor, being this decrease more expressive to the cathodic branch. Overall, the same behavior previously seen from weight loss measurements and electrochemical impedance 
Table 4. Electrochemical parameters acquired from the EIS diagrams in the absence and presence of ACSE and its HMWF.

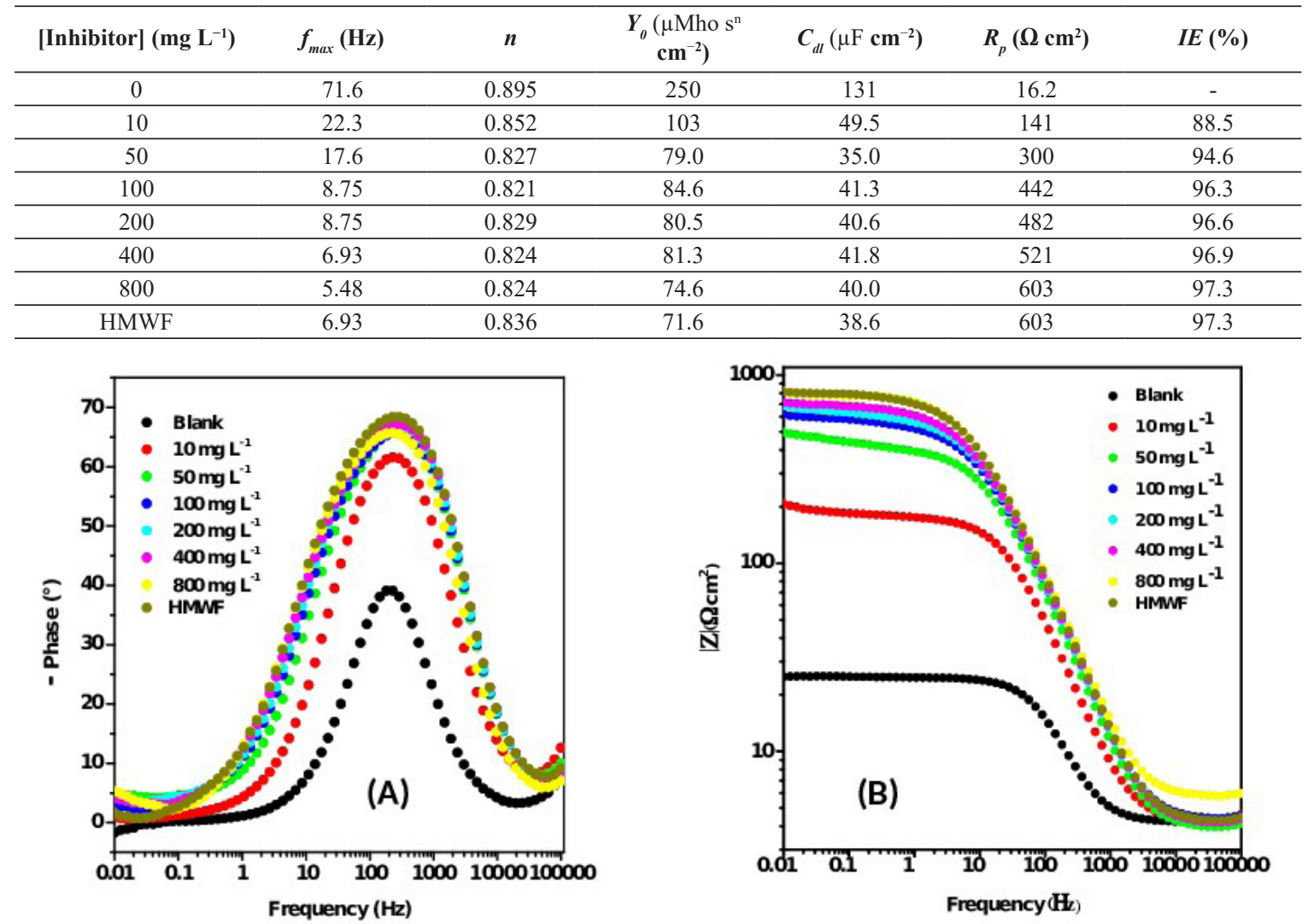

Figure 5. Bode diagrams of mild steel in $1 \mathrm{~mol} \mathrm{~L}^{-1} \mathrm{HCl}$ in the absence and presence of different concentrations of ACSE and at $400 \mathrm{mg} \mathrm{L}^{-1}$ of its HMWF: (A) Phase angle vs. Frequency and (B) Impedance module $v s$. Frequency.

Table 5. Data of straight lines obtained by linear adjustment.

\begin{tabular}{|c|c|c|c|}
\hline & Isoterms & Line Equation & $\mathbf{R}^{2}$ \\
\hline Langmuir & $\frac{C}{\theta}=\frac{1}{K}+C$ & $y=1.0264 x+1.4645$ & 0.9999 \\
\hline Temkin & $\theta=\left(\frac{-2.303}{2 a}\right) \log K+\left(\frac{-2.303}{2 a}\right) \log C$ & $y=0.0449 x+0.8576$ & 0.7816 \\
\hline Flory-Huggins & $\log \left(\frac{\theta}{C}\right)=\log K+x \log (1-\theta)$ & $y=2.7585 x+1.6563$ & 0.8974 \\
\hline El-Awady & $\log \left(\frac{\theta}{1-\theta}\right)=\log K+y \log C$ & $y=0.3475 x-0.6174$ & 0.8977 \\
\hline
\end{tabular}

${ }^{*} C$ is the ACSE concentration; $\mathrm{K}$ is the adsorption constant, $a$ is the lateral interaction parameter between the adsorbed molecules, $x$ is the number of water molecules substituted by a single inhibitor molecule and $y$ is the number of inhibitor molecules adsorbed in a given active site.

is maintained, where ACSE and its HMWF reached an $I E$ of $94.2 \%$ at 800 and $400 \mathrm{mg} \mathrm{L}^{-1}$, respectively, suggesting that probably the macromolecules present an important role in the inhibitory action of the ACSE towards the mild steel corrosion.

The presence of ACSE and its HMWF displaced the $O C P$ to more positive values with a maximum displacement of $+24 \mathrm{mV}$ while the $E_{\text {corr }}$ shifted to more negative values, with a maximum displacement of $-26 \mathrm{mV}$ in the presence of $400 \mathrm{mg} \mathrm{L}^{-1}$ ACSE, demonstrating that the extract acts as a mixed-type inhibitor with a cathodic character when polarized. The anodic Tafel constant did not significantly change with the extracts addition, suggesting that both ACSE and its HMWF do not change the mechanism of the anodic reaction ${ }^{11,23,29}$. However, the cathodic Tafel constant increased (in module) from the addition of $50 \mathrm{mg} \mathrm{L}^{-1}$ of ACSE and its HMWF which can be explained by a change of the cathodic reaction mechanism. These results suggest that the ACSE and its HMWF act like most organic compounds, where the screening effect is added to the activation effect.

Both ACSE and its HMWF are mixed type where the screening effect is added to the activation effect. They act by 

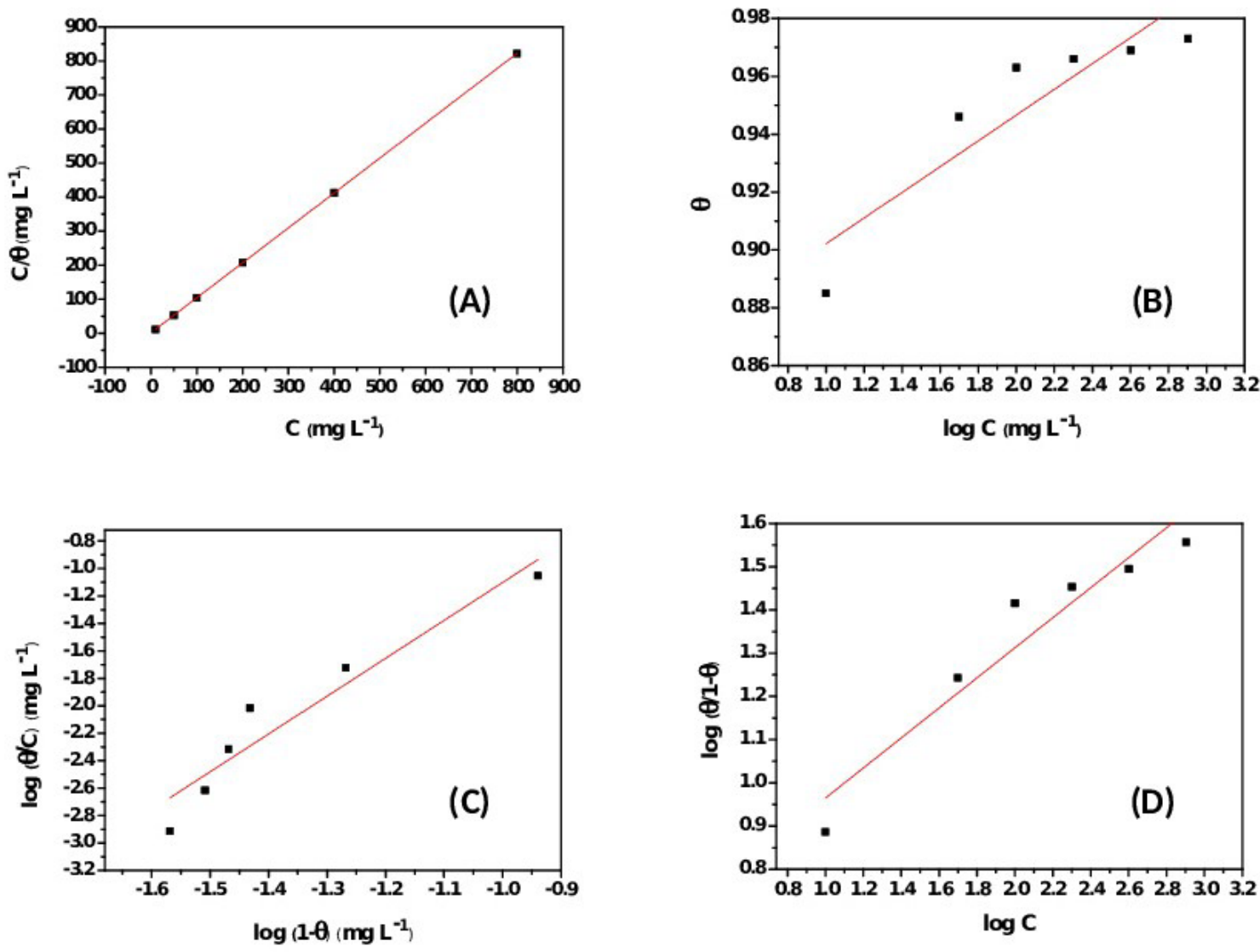

Figure 6. Adsorption isothermsof (A) Langmuir, (B) Temkin, (C) Flory-Huggins and (D) El-Awady for ACSEon the mild steel surface in $1 \mathrm{~mol} \mathrm{~L}^{-1} \mathrm{HCl}$ solution.

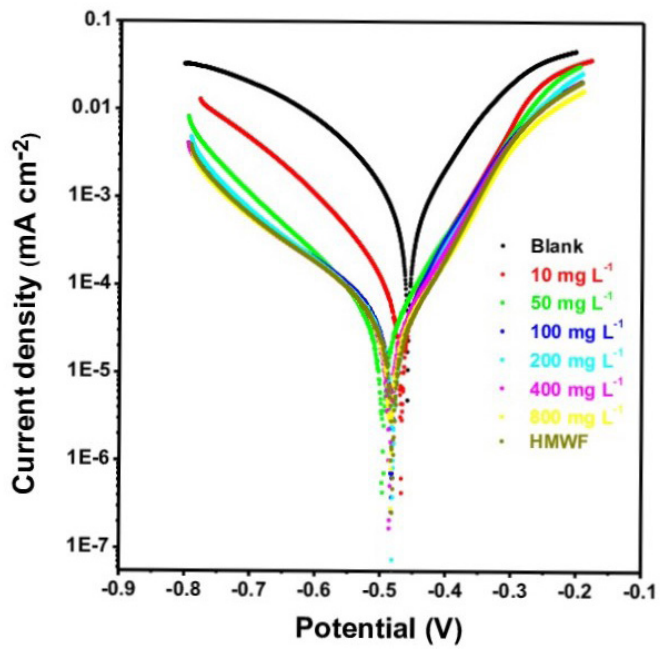

Figure 7. Polarization curves of mild steel in $1 \mathrm{~mol} \mathrm{~L}^{-1} \mathrm{HCl}$ in the absence and presence of different concentrations ACSE and at $400 \mathrm{mg} \mathrm{L}^{-1}$ of its HMWF.

a mixed type mechanism since the apparent activation energy decreased with their addition. Although normalized $R_{p}$ results are equal to the blank result the normalized $C_{d l}$ do not present the same behavior. If the inhibitors showed the pure blocking effect, acting only by surface screening their both normalized $R_{p}$ and $C_{d l}$ values should be equal to the blank results with the correction of the electroactive area, i.e., normalizing these two quantities by $(1-\theta)$, being $\theta$ determined by electrochemical impedance diagrams (Table 4). Table 7 shows that the $C_{d l}$ values do not keep constant with the area normalization ${ }^{38}$. According to the Fernandes et al. ${ }^{38}$, in the presence of their inhibitor the $C_{d l}$ was mainly related to the electroactive area $(1-\theta)$. However, if the normalization is performed for each extract concentration the $C_{d l}$ values did not keep constant how it should be. Certainly, their inhibitor is a mixed type where the screening effect is added to the activation effect.

The behavior seen with the HMWF where the $I E$ was equal to its total extract (ACSE) was also seen in our previous works with gorse, coffee husk and grains, biomass of Spirulina Maxima microalgae and barley agro-industrial residues aqueous extracts ${ }^{10-12,16,21,23,24}$. All these studies reinforce the hypothesis that macromolecules (proteins or polysaccharides) are probably responsible for the inhibitive action which would explain the deviation of a unit in the angular coefficient of Langmuir equation, allowing to suggest that the relation between active site for each adsorbed molecule is not of one unit ${ }^{9-21,39}$.

According to S. Banerjee et al. ${ }^{40}$, polymers maybe a better choice, as they have long chain molecules and show 
Table 6. Electrochemical parameters acquired from Tafel's extrapolation for mild steel in $1 \mathrm{~mol} \mathrm{~L}^{-1} \mathrm{HCl}$ in the absence and presence of CSE.

\begin{tabular}{|c|c|c|c|c|c|c|}
\hline $\begin{array}{c}\text { Inhibitor } \\
\left(m g L^{-1}\right)\end{array}$ & $\begin{array}{c}E_{O C P} \\
(m V v S S C E)\end{array}$ & $\begin{array}{c}E_{\text {corr }} \\
(\boldsymbol{m} \boldsymbol{V} \boldsymbol{S} S C E)\end{array}$ & $\begin{array}{c}j_{\text {corr }} \\
\left(\boldsymbol{m A c m ^ { - 2 }}\right)\end{array}$ & $\begin{array}{c}-\beta_{c} \\
\left(\mathrm{mVdec}^{-1}\right)\end{array}$ & $\begin{array}{c}\beta_{a} \\
\left(m \text { dec }^{-1}\right)\end{array}$ & $\begin{array}{l}I E \\
(\%)\end{array}$ \\
\hline 0 & -503 & -447 & $6.69 \times 10^{-1}$ & 121 & 76.9 & - \\
\hline 10 & -479 & -459 & $7.90 \times 10^{-2}$ & 110 & 78.8 & 88.2 \\
\hline 50 & -496 & -466 & $4.09 \times 10^{-2}$ & 166 & 72.1 & 93.9 \\
\hline 100 & -494 & -470 & $4.12 \times 10^{-2}$ & 167 & 67.7 & 93.8 \\
\hline 200 & -492 & -468 & $4.06 \times 10^{-2}$ & 170 & 73.3 & 93.9 \\
\hline 400 & -497 & -473 & $4.05 \times 10^{-2}$ & 167 & 80.5 & 93.9 \\
\hline 800 & -490 & -469 & $3.88 \times 10^{-2}$ & 167 & 86.4 & 94.2 \\
\hline HMWF & -493 & -462 & $3.91 \times 10^{-2}$ & 180 & 75.5 & 94.2 \\
\hline
\end{tabular}

Table 7. Normalized $R_{p}, C_{d l}$ obtained for mild steel immersed in $1 \mathrm{~mol} \mathrm{~L}^{-1} \mathrm{HCl}$ solution in the absence and in the presence of ACSE and its HMWF considering the fraction of the surface covered by adsorbed molecules $(\theta)$ from the electrochemical impedance measurements.

\begin{tabular}{|c|c|c|c|c|}
\hline \multirow{2}{*}{ [Inhibitor] } & \multirow{3}{*}{$\theta$} & \multirow{3}{*}{$(1-\theta)$} & \multirow{2}{*}{$\begin{array}{c}\text { Normalized } \\
R_{p}\end{array}$} & \multirow{2}{*}{$\begin{array}{c}\text { Normalized } \\
C_{d l} \\
\end{array}$} \\
\hline & & & & \\
\hline$\left(\mathrm{mg} \mathrm{L}^{-1}\right)$ & & & $\left(\Omega \mathrm{cm}^{2}\right)$ & $\left(\mu \mathrm{F} \mathrm{cm} \mathrm{cm}^{-2}\right)$ \\
\hline \multicolumn{5}{|c|}{ Aqueous cotton seeds extract } \\
\hline 0 & - & - & 16.2 & 131 \\
\hline 10 & 0.885 & 0.115 & 16.2 & 430 \\
\hline 50 & 0.946 & 0.054 & 16.2 & 648 \\
\hline 100 & 0.963 & 0.037 & 16.4 & 1116 \\
\hline 200 & 0.966 & 0.034 & 16.4 & 1194 \\
\hline 400 & 0.969 & 0.031 & 16.2 & 1348 \\
\hline 800 & 0.973 & 0.027 & 16.3 & 1481 \\
\hline \multicolumn{5}{|c|}{ HMWF } \\
\hline 400 & 0.973 & 0.027 & 16.3 & 1430 \\
\hline
\end{tabular}

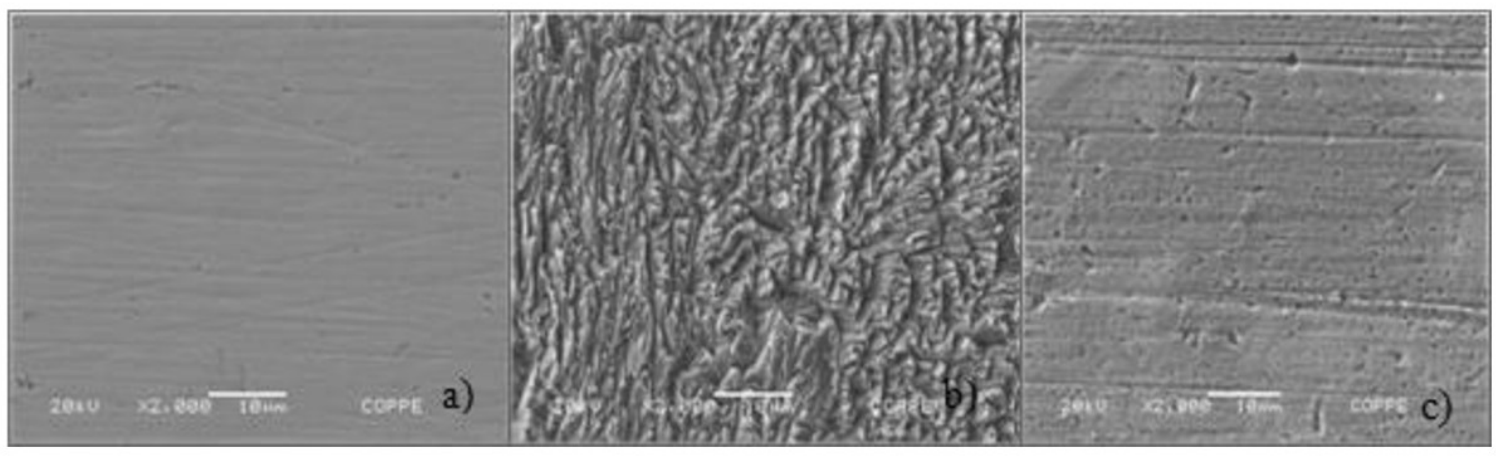

Figure 8. SEM micrographs of the mild steel indicating (A) the surface abraded before the immersion test, (B) the surface after immersion in $1 \mathrm{~mol} \mathrm{~L}^{-1} \mathrm{HCl},(\mathrm{C})$ the surface after immersion in $1 \mathrm{~mol} \mathrm{~L}^{-1} \mathrm{HCl}$ containing ACSE.

high inhibition efficiency at very low concentration in most aggressive media. For a chemically modified natural polysaccharide the authors found $96.6 \%$ of IE at $100 \mathrm{ppm}$ using EIS data. In the work of Haruna et al. ${ }^{41}$, the inhibitory action of gelatin on carbon steel in an acid medium was studied. This protein proved to be a good inhibitor with an efficiency of $88.1 \%$ for $2.5 \mathrm{w} / \mathrm{v}$ using EIS data.

In our work, the aqueous cotton seed extract acted as a good corrosion inhibitor reaching an inhibition efficiency of $95.7 \%$ after $24 \mathrm{~h}$ of immersion for $800 \mathrm{mg} \mathrm{L}^{-1}$ inhibitor concentration. From Rp data, it was seen that $400 \mathrm{mg} \mathrm{L}^{-1}$ of the high molecular weight fraction isolated from ACSE showed inhibition efficiency equal to $97.3 \%$, where as ACSE presented $96.9 \%$, suggesting that the macromolecules present a fundamental participation in the inhibitive process.
The literature results with gelatin and polysaccharides corroborates our hypothesis.

\subsection{Surface analysis}

Figure 8 presents the SEM micrographs for the mild steel. Figure 8a shows the abraded surface of the mild steel, without acidic exposition. The surface immersed in the acid medium without the inhibitor was strongly corroded leaving it rough; however, the surface immersed in the acid medium in the presence of the ACSE showed a smoother surface, indicating therefore that the surface was protected by the extract, which corroborates all the previously discussed results. These analyses show that the aqueous cotton seed extract acted as a good corrosion inhibitor of mild steel, as indicated by the gravimetric and electrochemical tests. 


\section{Conclusions}

Cotton seed extract was found to be an effective natural corrosion inhibitor for mild steel in $1 \mathrm{~mol} \mathrm{~L}^{-1}$ hydrochloric acid aqueous medium, as well as its high molecular weight fraction. The inhibitory action may be related to the presence of proteins and polysaccharides present in cotton seeds.

The results obtained by the gravimetric analyses showed an increase of the inhibition efficiency with the increase of the extract concentration and the immersion time. The results with temperature varying showed that the inhibitor adsorption is of chemical nature. The inhibitor adsorption followed the Langmuir isotherm model, which admits the formation of a monolayer of the inhibitor molecules on the metal surface.

The electrochemical results indicated that the inhibitory molecules in both ACSE and its HMWF adsorb in the metal surface acting as a mixed type inhibitor like the majority of organic compounds, where the screening effect is added to the activation effect.

The surface analysis corroborated the gravimetric and electrochemical tests and showed that mild steel surface is much less corroded when in the presence of aqueous cotton seed extract.

\section{Acknowledgment}

I. S. H. thanks CAPES for research fellowship. The authors thank CNPq (Conselho Nacional de Desenvolvimento Científico e Tecnológico) for financial support (process number 424306/2016-6 and 312005/2018-0).

\section{Referências}

1. Leitão GB, Gentil V. Corrosão. 3. ed. Rio de Janeiro: Livros Técnicos e Científicos; 1996.

2. He X, Mao J, Ma Q, Tang Y. Corrosion inhibition of perimidine derivatives for mild steel in acidic media: electrochemical and computational studies. J Mol Liq. 2018;269:260-8.

3. Khan G, Newaz KMS, Basirun WJ, Ali HBM, Faraj FL, Khan GM. Application of natural product extracts as green corrosion inhibitors for metals and alloys in acid pickling processes- a review. Int J Electrochem Sci. 2015;10(8):6120-34.

4. Farag AA, Ismail AS, Migahed MA. Environmental-friendly shrimp waste protein corrosion inhibitor for carbon steel in $1 \mathrm{M} \mathrm{HCl}$ solution. Egypt. J. Pet. 2018;27(4):1187-94.

5. Liao LL, Mo S, Luo HQ, Li NB. Corrosion protection for mild steel by extract from the waste of lychee fruit in $\mathrm{HCl}$ solution: experimental and theoretical studies. J Colloid Interface Sci. 2018;520:41-9.

6. Li X, Deng S, Fu H. Inhibition of the corrosion of steel in $\mathrm{HCl}, \mathrm{H} 2 \mathrm{SO} 4$ solutions by bamboo leaf extract. Corros Sci. 2012;62:163-75.

7. De Barros IB, Kappel MAA, Dos Santos PM, Da Veiga VF Jr, D'Elia E, Bastos IN. The inhibitory action of bauhinia purpurea extracts on the corrosion of carbon steel in sulfuric acid medium. Mater Res. 2016;19(1):187-94.

8. Torres VV, Rayol VA, Magalhães M, Viana GM, Aguiar LCS, Machado SP, et al. Study of thioureas derivatives synthesized from a green route as corrosion inhibitors for mild steel in $\mathrm{HCl}$ solution. Corros Sci. 2014;79:108-18.

9. Torres VV, Cabral GB, Silva ACG, Ferreira KCR, D'Elia E. Inhibitory action of papaya seed extracts on the corrosion of carbon steel in $1 \mathrm{Mol} \mathrm{L}-1 \mathrm{HCl}$ solution. Quim Nova. 2016;39(4):423-30.
10. Trindade R S, Dos Santos MR, Cordeiro RFB, D'Elia E. A study of the gorse aqueous extract as a green corrosion inhibitor for mild steel in $\mathrm{HCl}$ aqueous solution. Green Chem Lett Rev. 2017;10(4):444-54.

11. Cordeiro RFB, Belati AJS, Perrone D, D’Elia E. Coffee husk as corrosion inhibitor for mild steel in $\mathrm{HCl}$ media. Int J Electrochem Sci. 2018;13(12):12188-207.

12. dos Santos ÉC, Cordeiro R, Santos M, Rodrigues PRP, Singh A, D'Elia E. Barley agro-industrial residues as corrosion inhibitor for mild steel in $1 \mathrm{~mol} \mathrm{~L}-1 \mathrm{HCl}$ Solution. Mater Res. 2019;22(2):1-14.

13. Da Rocha JC, Da Cunha Ponciano Gomes JA, D'Elia E. Aqueous extracts of mango and orange peel as green inhibitors for carbon steel in hydrochloric acid solution. Mater Res. 2014;17(6):1581-7.

14. de Assunção Araújo Pereira SS, Pêgas MM, Fernández TL, Magalhães M, Schöntag TG, Lago DC, et al. Inhibitory action of aqueous garlic peel extract on the corrosion of carbon steel in $\mathrm{HCl}$ solution. Corros Sci. 2012;65:360-6.

15. De Assis BVR, Meira FO, Pina VGSS, De Andrade GF, Cotrim BA, De Resende GO, et al. Inhibitory effect of piper Nigrum L. extract on the corrosion of mild steel in acidic media. Rev. Virtual Quim. 2015;7(5):1830-40.

16. Souza ECCA, Ripper BA, Perrone D, D'Elia E. Roasted coffee extracts as corrosion inhibitors for mild steel in $\mathrm{HCl}$ solution. Mater Res. 2016;19(6):1276-85.

17. Raja PB, Sethuraman MG. Natural products as corrosion inhibitor for metals in corrosive media - a review. Mater Lett. 2008;62(1):113-6.

18. Chigondo M, Chigondo F. Recent natural corrosion inhibitors for mild steel: an overview. J. Chem. 2016;2016:6208937.

19. De Mendonça Santos A, De Almeida TF, Cotting F, Aoki IV, De Melo HG, Capelossi VR. Evaluation of castor bark powder as a corrosion inhibitor for carbon steel in acidic media. Mater Res. 2017;20(suppl 2):492-505

20. Sulay ZK, Victor AU, Obed B, Olufemi AO. Kinetics and thermodynamic study of inhibition potentials by ethoxyethane extracts of cochlospermum tinctorium for the oxoacid corrosion of mild steel. Int. J. Mater. Chem. 2015;5(3):64-76.

21. Varvara S, Bostan R, Bobis O, Găină L, Popa F, Mena V, et al. Propolis as a green corrosion inhibitor for bronze in weakly acidic solution. Appl Surf Sci. 2017;426:1100-12.

22. Hassannejad H, Nouri A. Sunflower seed hull extract as a novel green corrosion inhibitor for mild steel in $\mathrm{HCl}$ solution. $\mathrm{J} \mathrm{Mol}$ Liq. 2018;254:377-82.

23. Santana C, da Cunha J, Rodrigues J, GrecoDuarte J, Freire D, D'Elia E. Aqueous extracts of the castor beans as a corrosion inhibitor of mild steel in $\mathrm{HCl}$ media. J Braz Chem Soc. 2020;31(6):1225-38.

24. Lima KCS, Paiva VM, Ripper BA, Perrone D, Veiga AG, Simões G, et al. Glycine max meal extracts as corrosion inhibitor for mild steel in sulphuric acid solution. J. Mater. Res. Tech. 2020;9(6):12756-72.

25. Santos DC. Physical and chemical composition of seeds of herbaceous cotton lines cultivated in sequeiro regimes. Agropecuária Técnica. 2011;32(1):16-20.

26. Rodrigues LS, do Valle AF, D'Elia E. Biomass of microalgae spirulina maxima as a corrosion inhibitor for 1020 carbon steel in acidic solution. Int J Electrochem Sci. 2018;13(7):6169-89.

27. ASTM International. ASTM G31-7. Standard Guide for Laboratory Immersion Corrosion Testing of Metals. West Conshohocken: ASTM International; 2013.

28. Akalezi CO, Ogukwe CE, Ejele EA, Oguzie EE. mild steel protection in acidic media using mucuna pruriens seed extract. Int. J. Corros. Scale Inhib. 2016;5(2):132-46.

29. Zhao T, Mu G. The adsorption and corrosion inhibition of anion surfactants on aluminium surface in hydrochloric acid. Corros Sci. 1999;41(10):1937-44. 
30. Amin MA, Abd El-Rehim SS, El-Sherbini EEF, Bayoumi RS. The inhibition of low carbon steel corrosion in hydrochloric acid solutions by succinic acid. part i. weight loss, polarization, EIS, PZC, EDX and SEM studies. Electrochim Acta. 2007;52(11):3588-600.

31. Quraishi MA, Singh A, Singh VK, Yadav DK, Singh AK. Green approach to corrosion inhibition of mild steel in hydrochloric acid and sulphuric acid solutions by the extract of murraya koenigii leaves. Mater Chem Phys. 2010;122(1):114-22.

32. Popova A, Sokolova E, Raicheva S, Christov M. AC and DC study of the temperature effect on mild steel corrosion in acid media in the presence of benzimidazole derivatives. Corros Sci. 2003;45(1):33-58.

33. Zhang QB, Hua YX. Corrosion inhibition of aluminum in hydrochloric acid solution by alkylimidazolium ionic liquids. Mater Chem Phys. 2010;119(1-2):57-64.

34. Kuznetsov YI, Andreev NN, Vesely SS. Why we reject papers with calculations of inhibitor adsorption based on data on protective effects. Int. J. Corros. Scale Inhib. 2015;4(2):108-9.

35. Abboud Y, Tanane O, El Bouari A, Salghi R, Hammouti B, Chetouani A, et al. Corrosion inhibition of carbon steel in hydrochloric acid solution using pomegranate leave extracts. Corros Eng Sci Technol. 2016;51(8):557-65.
36. Amin MA, Ahmed MA, Arida HA, Kandemirli F, Saracoglu M, Arslan T, et al. Monitoring corrosion and corrosion control of iron in $\mathrm{HCl}$ by non-ionic surfactants of the TRITON-X Series Part III. Immersion time effects and theoretical studies. Corros Sci. 2011;53(5):1895-909.

37. Hsu CH, Mansfeld F. Concernng the conversion of the constant phase element parameter y0 into a capacitance. Corros Sci. 2001;57(9):747-8.

38. Fernandes CM, Ferreira Fagundes TS, Escarpini dos Santos N, Shewry M, Rocha T, Garrett R, et al. Ircinia strobilina crude extract as corrosion inhibitor for mild steel in acid medium. Electrochim Acta. 2019;312:137-48

39. Matos LAC, Taborda MC, Alves GJT, da Cunha MT, Banczek EP, Oliveira MF, et al. Application of an acid extract of barley agro-industrial waste as a corrosion inhibitor for stainless steel AISI 304 in H 2 SO 4. Int J Electrochem Sci. 2018;13(2):1577-93.

40. Banerjee S, Srivastava V, Singh MM. Chemically modified natural polysaccharide as green corrosion inhibitor for mild steel in acidic medium. Corros Sci. 2012;59:35-41.

41. Haruna K, Obot IB, Ankah NK, Sorour AA, Saleh TA. Gelatin: a green corrosion inhibitor for carbon steel in oil well acidizing environment. J Mol Liq. 2018;264:515-25. 